\title{
Analysis of Factors Affecting the Performance of Fixed Income Mutual Funds in Indonesia (Study on RDPT Registered on OJK for the Period 2014-2018)
}

\author{
Ferby Wijaya Kusumawati ${ }^{1}$, V. Santi Paramita ${ }^{2}$ \\ \{ferbywijayak@gmail.com¹ ${ }^{1}$ santi.pramit@gmail.com² ${ }^{2}$
}

Management Department, Faculty of Economics and Business, Jenderal Achmad Yani University, Indonesia ${ }^{1}$, Management Department, Faculty of Economics and Business, Jenderal Achmad Yani University, Indonesia ${ }^{2}$

\begin{abstract}
The aim of this research is to determine the influence of the past performance, fund size, inflation and interest rate toward fixed income mutual funds' performance in Indonesia on 2014-2018. This research used 95 fixed income mutual funds which listed and published by OJK and still active during the period on 2014-2018. This research uses a quantitative approach and use pooled regression to determine the effects between past performances, fund size, inflation and interest rate toward fixed income mutual funds' performance. The result of this research shows that partially past performance and interest rate are have a significantly positive influence and inflation have a significantly negative influence. Meanwhile fund size is partially has insignificant influence. While simultaneously, past performance, fund size, inflation and interest rate have a significant influence with the coefficient of determination is $97.9 \%$ while the rest is influenced by other variables not included in this research.
\end{abstract}

Keywords: Mutual Fund, Performance, Past Performance, Fund Size, Inflation, Interest Rates.

\section{Introduction}

The issue of an economic recession is being discussed, several countries have experienced a recession where the country's GDP has experienced negative growth [1]. However, amid in uncertainty in the world economy, Indonesia can be said to have had a fairly good and stable economic condition in recent years, as evidenced by the achievement of economic growth of $5.17 \%$ in 2018 and this trend of economic growth above 5\% will continue [2]. One of the factors that can increase economic growth is infrastructure development [3]. Building infrastructure is the same as building the future of civilization. Through the acceleration of equitable infrastructure development, it is hoped that it can create strong connectivity between regions that will improve the quality of life of the people. Limited funding is the main problem for the government in carrying out its work program, therefore the government and stakeholders often work together in issuing policies to explore potential funding, including by facilitating licensing and encouraging the use of capital market instruments for infrastructure financing [4].

Capital Market defines as activities related to Public Offerings and Securities trading, Public Companies related to the Securities they issue, as well as institutions and professions related to Securities. The capital market has an important role in the economy of a country because the capital market carries out two functions, as a financing business and for people to invest in long-term 
financial instruments [5]. Everyone is faced with many choices in determining the resources they have for consumption now and in the future. Investment is defined as a commitment to invest several funds today to obtain profits in the future [6].

The theory of modern portfolio investment is minimizing risk and increasing returns by diversifying investment, an investment instrument that applies this principle is Mutual Funds [7]. Mutual funds is a company that pools money from a group of people with investment goals to buy securities in money market or equity market instrument [8]. It embodies professional management, portfolio diversification and low transaction cost [9]. Mutual Funds are an alternative for the investor to invest, especially small investors who don't have much time and expertise to calculate the risk of their investment or the limited knowledge of investors [10]. Mutual funds offer higher long-term benefits than savings and time deposits, but it must be realized that basically, all investments have their respective risks [11].

Since January 2014 - June 2019, mutual funds have experienced very rapid growth, as seen from the number, NAV, and UP of Mutual Funds which have continued to increase every year, but if seen from the yield there are fluctuations and tend to decline. The choice of mutual funds can be done by knowing the performance of the mutual fund of their choice to invest in order to get optimal results. Mutual funds can be said to perform well if they have better market index performance [12]. By knowing the performance of the mutual fund that he will choose, it is hoped that investors will not suffer losses because they invest in mutual funds that are not performing well.

Mutual fund performance reflects the ability of a mutual fund product to generate returns, therefore the performance of a mutual fund is determined by the amount of return it receives. Mutual fund performance is influenced by various factors that determine whether a mutual fund is performing well or poorly. The first factor is Past Performance or past performance. The effect of past performance on current performance has been referred to as performance persistence [13]. The ability to generate mutual fund returns can be seen from their past performance and many investors believe that the management quality of managers can be seen through their past performance [12]. Belgacem (2011) in his research emphasizes that past performance is positively related to future performance, which means that past performance contains information about future performance. As well as the research results of Marna, et al (2017) and Desiyanti (2014) stated that there is persistence in mutual fund performance in Indonesia, which means that the past performance of mutual funds can be taken into consideration in the selection of mutual funds in Indonesia. The research conducted by Bitomo \& Muharam (2016) states that past performance has no effect on the performance of fixed income mutual funds but has an effect on equity funds and the money market.

The purpose of this research is to determine what factors affect the performance of fixed income mutual funds in Indonesia by using variables Past Performance (X1), Fund Size (X2) Inflation (X3) and Interest Rates (X4). This research is expected to add to the knowledge of financial management, especially in the field of investment and portfolio management. So that science in the field of investment and portfolio management can continue to be updated / developed, especially from the variables studied. 


\section{Literature Review}

\subsection{Past Performance}

The ability to generate mutual fund returns can be seen from their past performance and many investors believe that the management quality of managers can be seen through their past performance [12]. Belgacem (2011) in his research emphasizes that past performance is positively related to future performance, which means that past performance contains information about future performance. As well as the research results of Marna, dkk (2017) and Desiyanti (2014) stated that there is persistence in mutual fund performance in Indonesia, which means that the past performance of mutual funds can be taken into consideration in the selection of mutual funds in Indonesia. Then the research hypothesis is obtained:

$\mathrm{H}_{1}$ : Past Performance has a positive effect on the performance of fixed income mutual funds in Indonesia.

\subsection{Fund Size}

Mutual fund size is a reflection of the size of mutual funds based on managed funds which can be assessed from the amount of Total Net Asset [12]. The greater the TNA should have an impact on the flexibility of mutual fund services such as reducing the burden of dependency costs for its customers [17], and also large funds has better investment opportunities and more resource for research that leading to economic of scale [29]. In addition, according to Sukmaningrum \& Mahfud, (2016), a larger size of mutual funds allows mutual funds to diversify their assets, so large size of mutual funds can provide good performance for mutual funds. This is following with what was stated by Dwiperkasa \& Dharmastuti (2016), Wicaksono \& Sampurno, (2017) and Pratama \& Wirama (2018) which stated that the size of mutual funds has a positive and significant effect on mutual fund performance so that the greater the size of mutual funds that is reflected in the net asset value under management, the better the mutual fund's performance.

$\mathrm{H}_{2}$ : Fund Size has a positive effect on the performance of fixed income mutual funds in Indonesia.

\subsection{Inflation}

Inflation is a tendency for prices to rise continuously, the higher the price increase, the value of the currency will decrease and will affect the development of mutual funds [22]. The relative increase in inflation is a negative signal for investors. If there's a high inflation, it will reduces the investment assets of the investor. Inflation decrease risk aversion capacity among investors and they start switching themself from high risk securities to low risk securities[30]. Inflation can increase the company's income and costs, if the increase in production value is higher than the increase in price that can be enjoyed by the company, then the company's profitability will decrease which will affect the company's stock price and impact the performance of mutual funds (Mustofa \& Kusumawardhani, 2016). This supports the results of research conducted by and Rahmawati \& Nuris (2018) which states that the inflation rate affects the performance of Fixed Income Funds and Pratama \& Wirama (2018) which states that the inflation rate has a negative and significant effect on mutual fund performance. $\mathrm{H}_{3}$ : Inflation has a negative effect on the performance of fixed income mutual funds in Indonesia. 


\subsection{Interest rates}

When interest rates are increased, people tend to choose alternative instrument that provide higher interest rates. As a result, stocks and bonds are sold which causes the price of stocks, bonds or mutual funds to fall. Conversely, when interest rates are lowered, investors will look for instruments that provide a higher return than deposits, namely stocks and bonds, so that the demand for these instruments will increase and also increase the prices of stocks, bonds and mutual funds [32], thereby increasing returns and improving mutual fund performance. This is in line with the results of research by Hermawan \& Wiagustini (2016) and Wiradiyasa (2016) which state that interest rates have a negative effect on mutual fund performance.

$\mathrm{H}_{4}$ : Interest rates have a negative effect on the performance of fixed income mutual funds in Indonesia.

\subsection{Mutual Fund}

The objective of a mutual fund is to obtain an optimal return. In achieving return this optimal, mutual funds cannot be separated from their performance evaluation. Return mutual fund is known as the Net Asset Value (NAV), which is key in assessing the performance of mutual funds. Assessing the performance of a mutual fund can use the Sharpe Ratio. The formula for the Sharpe Ratio is as follows (Tandelilin, 2017:500):

$$
\hat{S}_{p}=\frac{\bar{R}_{p}-\overline{R F}}{\sigma_{T R}}
$$

The appraisal is seen based on the performance obtained from the previous period, so that Past Performance can be calculated using the formula [12]:

$$
\hat{S}_{p(t-1)}=\frac{\bar{R}_{p(t-1)}-\overline{R F_{(t-1)}}}{\sigma_{T R(t-1)}}
$$

The size of a mutual fund is a reflection of the size of the funds raised by the mutual funds [20]. The formula for calculating the size of the mutual fund (size fund) is as follows (Gusni et al., 2018):

$$
\text { Fund Size }=\text { Ln Net Asset Value }
$$

Inflation is the tendency for prices to rise generally and continuously. The formula for calculating the inflation rate is as follows [27]:

$$
\text { Inflasi }=\frac{I H K_{(t)}-I H K_{(t-1)}}{I H K_{(t-1)}} \times 100 \%
$$


Interest rates according to McTaggart (2003) in Hermawan \& Wiagustini (2016)can be interpreted as the number of funds received by the lender and paid as a percentage of the loan amount. The interest rate can be peroxide as follows:

$$
\text { BI rate }=\text { BI } 7-\text { day }(\text { Reverse }) \text { Repo Rate }
$$

\section{Methods}

In this study, researchers used a quantitative research approach. The form of problem formulation used in this research is descriptive and associative problem formulation. The population in this study was Fixed Income Mutual Funds operating in 2014-2018, which information on NAV was available at OJK in rupiah denominations of 218 Fixed Income Fund. As for this study, researchers used a purposive sampling technique, where the samples taken by researchers used certain considerations. That way the researchers set a sample with the criteria for Fixed Income Mutual Funds that were actively operating continuously from 2014-2018 and obtained a sample of 95 Fixed Income Fund. In this test, before testing the hypothesis, first a descriptive analysis is carried out, then the Chow test, the test Hausmann, and the test Lagrange Multiplier. The testing of hypotheses and analytical determination $\left(\mathrm{R}^{2}\right)$ using panel data regression analysis by E-views $10^{\text {th }}$ ver .

\section{Result and Discussion}

The average performance of fixed income mutual funds in Indonesia in 2014-2018 is -0.059, with the greatest performance having Sharpe index of 1,419 and the lowest with Sharpe index of $-1,766$. The average Past Performance of fixed income mutual funds in Indonesia in 2014-2018 was -0.052, with the largest performance having a Sharpe index the lowest with Sharpe index of 1.379of $-1,731$. The average Fund Size for fixed income mutual funds in Indonesia in 2014-2018 was 25,506, with the largest size being 28,267 and the smallest being 22,536. The highest inflation rate in Indonesia in 2014-2018 was in 2014 at 6.42\%, and the lowest inflation rate in 2018 was $3.2 \%$. The highest interest rate in Indonesia in 2014-2018 was in the year 2014 at $7.54 \%$ and the lowest interest rates in 2017 amounted $4.56 \%$.

\subsection{Chow Test}

Chow test is a test to select one of the models on panel data regression between Common Effect Model or Fixed Effect Model is most appropriate to use in estimating the model in this study. The chow test results indicate that this model has a probability F of 1.0000 greater than alpha 0.05 , so that HO is accepted, which means that the chosen model is the Common Effect Model.

\subsection{Haussmann Test}

Hausmann test is a test to select one of the models on panel data regression between Fixed Effect Model or Random Effect model the most appropriate is used to estimate the model in this study. The 
Haussmann test results indicate that this model has a chi-square probability of 1.0000 greater than alpha 0.05 , so that $\mathrm{H} 0$ is accepted, which means that the chosen model is the Random Effect Model.

\subsection{Selected Estimation Model}

Based on the three tests above, it can be seen that the model that the researcher uses the Random Effect Model. The following are the results of panel data regression using the approach Random Effect Model. Based on the table above, taking into account the numbers in the column coefficient, based on the table above, a panel data regression equation can be compiled using the Random Effect Model as follows:

Performance RD $=-0.066617+1.046745$ PP -0.002900 FS $-4.128888 \mathrm{I}+5.350077$

\subsection{Lagrange Multiplier Test}

Lagrange Multiplier test is a test to select one of the models on panel data regression between whether the Random Effect Model or Common Effect model the most appropriate is used to estimate the model in this study. The Lagrange multiplier test results show that this model has a probability of Brash-Pagan 0.0000 smaller than alpha 0.05 , so $\mathrm{H} 0$ is rejected, which means that the chosen model is the Random Effect Model.

How much the ability of the independent variable understudy can explain the dependent variable can be seen through the value of Adjusted $R$ Square. Value Adjusted $R$ Square in this study amounted to 0.978962 , which means that the independent variable understudy can explain $97.9 \%$ of the dependent variable, and the rest is explained by other variables not examined by the researcher.

Based t-test result, Past Performance has a significance level of $0.0000<0.05$, so Ho is rejected. So we can concluded that Past Performance has a significant effect on the performance of fixed income mutual funds in Indonesia. Partially Fund Size has a significance level of $0.2216>0.05$, so Ho is accepted. So it can be concluded that Fund Size does not have a significant effect on the performance of fixed income mutual funds in Indonesia. Partially inflation has a significance level of $0.0000<0.05$, so Ho is rejected. So it can be concluded that inflation has a significant effect on the performance of fixed income mutual funds in Indonesia. Partially interest rate has a significance level of $0.0000<0.05$, so Ho is rejected. So we can concluded that interest rate has a significant effect on the performance of fixed income mutual funds in Indonesia.

Based F-test result shows that simultaneously the independent variables Past Performance, Fund Size, inflation and interest rates significantly affect the performance of fixed income mutual funds because the significance value is $0.0000<0.05$, which means that Ho is rejected, which indicates that the variable Past Performance, Fund Size, Inflation and interest rates simultaneously influence the performance of fixed income mutual funds in Indonesia.

\subsection{The effect of past performance towards fixed income mutual funds performance}

The results of this study are following the research hypothesis, which states that past performance of mutual funds has a positive effect on current mutual fund performance. This condition occurs because the past performance of mutual funds is used as a reference by investors before investing in RDPT products because this reflects the performance of the RDPT concerned in the future, where the better the performance of mutual funds in the past, it will give a tendency perform well again in the 
future. The results of this study are in line with research conducted by Belgacem (2011) which confirms that past performance is positively related to future performance, which means that past performance contains information about future performance. The results of this study support the research results of Marna, et al (2017) and Desiyanti (2014) which state that there is persistence in mutual fund performance in Indonesia, which means that the past performance of mutual funds can be taken into consideration in the selection of mutual funds in Indonesia.

\subsection{The effect of fund size towards fixed income mutual funds performance}

The results of this study are not following the hypothesis proposed by the researcher, which states that mutual fund size has a positive effect on mutual fund performance. This is possible because investors do not use the size of the mutual fund as a benchmark in making investment decisions, where the size of the mutual fund is not considered by investors. In addition, In addition, smaller fund size tend to be able to manage their liquidity better, such as when the larger fund size experiences large-scale withdrawals by their investors, the mutual funds tend to experiences a liquidity difficulties which will decrease the return an will impact on its performance [24].. The results of this study are in line with research conducted by Hermawan \& Wiagustini (2016) which states that the size of mutual funds has no effect on mutual fund performance, which means that the size of mutual funds does not have an impact on changes in mutual fund performance. The results of this study support the results of this study. conducted by Gusni et al. (2018) and Sukmaningrum \& Mahfud (2016).

\subsection{The effect of inflation towards fixed income mutual funds' performance}

The results of this study are following the research hypothesis, which states that inflation has a negative effect on mutual fund performance. Because investors also think that the inflation rate can increase the company's income and costs, if the increase in production value is higher than the price increase that can be enjoyed by the company, then the company's profitability will decrease which will affect the company's stock price and impact the performance of mutual funds (Mustofa \& Kusumawardhani, 2016). The results of this study support the results of research conducted by Rahmawati \& Nuris (2018) dan Pratama \& Wirama (2018).

\subsection{The effect of interest rates towards fixed income mutual funds performance}

These results are not in line with research conducted by Hermawan \& Wiagustini (2016) and Wiradiyasa (2016) which states that interest rates negatively affect the performance of mutual funds, because the results of this study stated that the interest rate has a positive effect the performance of Fixed Income Funds. The results of this study are not following the research hypothesis. From the research results, there is no empirical evidence that the higher the interest rate, the lower the performance level of the fixed income mutual funds, this shows that in the research period interest rates do not directly influence investors' decisions to invest. This is possible, where increased interest rates do not cause investors to run to instruments other than Fixed Income Mutual Funds because investors still tend to invest their funds in this instrument, investors may still entrust their funds to be managed by their investment managers. Beside that, interest rates affect company profits and the company need to release their other bonds to get funds to cover their lack of funds that occur caused thee increase of interest rates. To attract the investors, the company will try to offer a high rate of return so that their bonds can be sold [33] because the increase of the interest rates indicate an increasing in borrowing costs, this implies that the risk faced by the investors also increase. Therefore, 
when the interest rates increasing, investors tend to ask for a higher rate of return as a form of compensation for the risk that they bear [34]. With the large amount of the bond that have been sold, it will increased the yields that will make the performance of the Fixed Income Mutual Fund increasing. The results of this study support the results of Wibowo (2011) which states that interest rates have a significant positive effect on mutual fund performance.

\section{Conclusion}

Based on the results of the research that the researchers have conducted and the discussion described in the previous chapter, the following conclusions can be drawn:

1. The highest performance conditions during 2014-2018 were achieved by Simas Danamas Mantap Plus Mutual Funds and the lowest by Schroder Dana Andalan II Mutual Funds The conditions were Past Performance highest in 2014-2018 occupied by Reksa Dana Simas Danamas Mantap Plus and the lowest by Mutual Fund Schroder Dana Andalan II. In addition, the Fund Size largest for 2014-2018 was owned by the Main Manulife Funds and the smallest during 2014-2018 by Mutual Fund PG Sejahtera. For conditions, the highest inflation was in 2014 while the lowest inflation was in 2018. Meanwhile, the highest interest rate was in 2014 and the lowest was in 2017.

2. Partial testing in this study states that the variable Past Performance has a positive effect, the variable fund size has no effect, the inflation variable has a negative effect and the interest rate variable has a positive effect on the performance of fixed income mutual funds in Indonesia in the 2014-2018 period.

3. Simultaneous testing in this study states that the variables Past Performance, Fund Size, inflation and interest rates together have an effect on the performance of fixed income mutual funds in Indonesia in the 2014-2018 period.

\section{Suggestions}

Based on the research that has been carried out, the researcher realizes that there are still many shortcomings and limitations possessed by researchers, both limited time, tools, knowledge and / or other resources, so to perfect this research allow the researcher to submit some suggestions that might be considered:

1. For further researchers, it is hoped that they can add other independent variables, both micro and macro, because this study only uses variables Past Performance, Fund Size, inflation and interest rate. In addition, mutual fund performance measurement can also use other performance indexes. In addition, the next researcher should add observation periods so that the research can be more up to date.

2. For investors, the results of this study can be used in making investment decisions, that investors must be more sensitive to economic changes that occur around them because the results of this study indicate that these changes can affect the performance of each fixed income mutual fund. 
3. For investment managers, the results of this study are expected to be able to make MIs evaluate their performance in the previous period, and serve as a reference for improvement so that their performance in the future will be even better.

\section{Acknowledgements}

Acknowledgements. The researchers are very grateful for the support from everyone who help the researcher to complete this research especially FEB and Ka. LLPM Unjani, Dr. Ferikawita Magdalena S., S.E., M.si., and Eka Yulianti, S.E., M.Si as reviewers who gives many inputs for this research and also Frido Saritua Simatupang, S.E., M.Si.

\section{References}

[1] R. Gumiwang, "Ekonomi Global Kian Lesu Apakah Indonesia Terancam Resesi," Tirto.id, 2019. [Online]. Available: https://tirto.id/ekonomi-global-kian-lesu-apakah-indonesia-terancam-resesi-eg3y.

[2] Menko Perekonomian, "Mendorong Pertumbuhan Ekonomi melalui Infrastruktur," ekon.go.id, 2018. [Online]. Available: https://ekon.go.id/berita/view/mendorong-pertumbuhan-ekonomi.4321.html.

[3] M. Lestari, "Ekonomi Dan Pemerataan Ekonomi Indonesia ( Studi Pada Badan Pusat Statistik Tahun 2003-2017 )," J. Adm, vol. 70, no. 1, 2019.

[4] T. Hamdani, "Butuh Banyak Dana Segar, Kontribusi Pasar Modal Bangkitkan Perekonomian," Koran SINDO, 2017.

[5] www.idx.co.id, "Pengantar Pasar Modal." [Online]. Available: https://idx.co.id/investor/pengantarpasar-modal/. [Accessed: 23-Sep-2019].

[6] E. Tandelilin, Pasar Modal : Portofolio dan Investasi, 1st ed. Yogyakarta: Kanisius, 2017.

[7] R. Rachmawati, S. Wahyudi, I. Rini, and D. Pangestuti, "Funds Manager and Mutual Funds Characteristics on Mutual Funds Performance: Empirical Evidence of Equity Mutual Funds in Indonesia,” Int. J. Financ. Res., vol. 11, no. 2, pp. 77-87, 2020.

[8] V. S. Paramita, F. M. Sembiring, and D. Safitri, "Measuring Selectivity and Market Timing Performance of Mutual Funds in Indonesia Using Single and Dual Beta Models," KnE Soc. Sci., vol. 3, no. 10, pp. 1800-1809, 2018.

[9] D. Chen, C.-L. Chuang, J.-R. Lin, and C.-L. Lan, "Market Timing and Stock Selection Ability of Mutual Fund Managers in Taiwan: Applying The Traditional and Conditional Approaches," Int. Res. J. Appl. Financ., no. January, 2013.

[10] T. Rustendi, "Analisis Kinerja Reksa Dana Pendapatan Tetap, Reksa Dana Saham, dan Reksa Dana Campuran (Studi di Bursa Efek Indonesia - BEI)," J. Ekon. Manaj., vol. 3, no. 2, pp. 83-95, 2017.

[11] I. Rini, D. Pangestuti, S. Wahyudi, R. Robiyanto, and K. Kunci, "Performance Evaluation of Equity Mutual Funds in Indonesia," J. Keuang. dan Perbank., vol. 21, no. 4, pp. 527-542, 2017.

[12] H. Bitomo and H. Muharam, "Analisis Faktor-Faktor Yan Mempengaruhi Kinerja Reksa Dana Di Indonesia ( Studi Empiris Pada Reksa Dana Konvensional di Indonesia Periode 2012-2014 )," Diponegoro J. Manag., vol. 5, no. 2, pp. 1-14, 2016.

[13] I. Kaur, "Effect of mutual funds characteristics on their performance and trading strategy: A dynamic panel approach Effect of mutual funds characteristics on their performance and trading strategy: A dynamic panel approach," Cogent Econ. Financ., vol. 6, no. 1, pp. 1-17, 2018. 
[14] S. Ben Belgacem, "Predicting Tunisian mutual fund performance using dynamic panel data model," $J$. Risk Financ., vol. 12, no. 3, pp. 208-225, 2011.

[15] Y. Marna, R. Desiyanti, and Yulhelmi, “Analisis Kinerja Reksa Dana Di Indonesia,” UNES J. Soc. Econ. Res., vol. 2, p. 128, 2017.

[16] R. Desiyanti, "Persistensi dan Konsistensi Kinerja Reksa Dana di Indonesia," J. Kaji. Manaj. Bisnis, vol. 3, no. 1, pp. 1-18, 2014.

[17] J. D. M. S. Agung and I. W. P. Wirasedana, "Analisis kinerja reksa dana saham di indonesia," E-Jurnal Akunt. Univ. Udayana, vol. 7, no. 1, pp. 250-265, 2014.

[18] B. Dwiperkasa and C. F. Dharmastuti, "Karakteristik reksa dana dan kinerja reksa dana saham di indonesia," J. Manaj., vol. 13, no. 1, pp. 94-116, 2016.

[19] M. P. Wicaksono and R. D. Sampurno, “Analisis Pengaruh Fund Age, Market Timing Ability, Stock Selection Skill , Portfolio Turnover Dan Fund Size Terhadap Kinerja Reksa Dana Syariah Periode 2013 2015," Diponegoro J. Manag., vol. 6, pp. 1-11, 2017.

[20] I. P. B. S. Pratama and D. G. Wirama, "E-Jurnal Akuntansi Universitas Udayana Pengaruh Inflasi , IHSG, Ukuran Dan Umur Pada Kinerja Reksa Dana," vol. 23, pp. 842-870, 2018.

[21] F. Kusumastiti and M. N. H. Ryandono, "Pengaruh Risiko Sistematis, Market Timing Dan Ukuran Dana Terhadap Kinerja Reksa Dana Pendapatan Tetap Syariah Di Indonesia Periode 2014-1018,” J. Ekon. Syariah Teor. dan Terap., vol. 6, no. 12, pp. 2409-2421, 2019.

[22] D. Hermawan and P. Wiagustini, "Pengaruh Inflasi, Suku Bunga, Ukuran Reksa Dana dan Umur Reksa Dana Terhadap Kinerja Reksa Dana,” E-Jurnal Manaj. Unud, vol. 5, no. 5, pp. 3106-3133, 2016.

[23] Gusni, Silviana, and F. Hamdani, "Factors Affecting Equity Mutual Fund Performance : Evidence from Indonesia," Invest. Manag. Financ. Innov., vol. 15, no. 1, pp. 0-9, 2018.

[24] G. Sukmaningrum and M. K. Mahfud, "Analisis Pengaruh Fund Cash Flow , Fund Size , Fund Longevity , Expense Ratio Dan Turnover Ratio Terhadap Kinerja Reksa Dana ( Studi Kasus : Reksa Dana Pendapatan Tetap Periode Tahun 2011-2015 )," vol. 5, no. 3, pp. 1-11, 2016.

[25] S. A. Rahmawati and D. M. Nuris, "Pengaruh Faktor-Faktor Perekonomian Makro Terhadap Kinerja Reksadana Pendapatan Tetap Periode 2015-2017," J. Nominal, Vol. Vii, No. 2, 2018.

[26] A. Wibowo, "Pengaruh Variabel Makro Ekonomi Terhadap Kinerja Reksadana Pendapatan Tetap Di Indonesia," J. Akuntansi, Manaj. Bisnis dan Sekt. Publik, vol. 7, no. 2, 2011.

[27] C. Setiawan, N. Putu, and K. Wati, "Factors Affecting the Performance of Sharia Equity Funds in Indonesia," Iran. J. Manag. Stud., vol. 12, no. 4, pp. 481-508, 2019.

[28] I. Wiradiyasa, "Analisis Pengaruh Inflasi, Suku Bunga SBI, dan Kurs terhadap Kinerja Reksa Dana Syariah Indonesia," J. Ilm. Mhs. FEB Univ. Brawijaya, vol. 4, no. 1, 2016.

[29] S. Babbar and S. Sehgal, "Mutual Fund Characteristics and Investment Performance in India," Manag. Labour Stud., vol. 43, no. 1-2, pp. 1-30, 2018.

[30] M. Garg, Shobhit, and S. Srivastava, "Appraising relationship of selected macro-economic variables on mutual funds," Int. J. Sci. Technol. Res., vol. 9, no. 2, pp. 4676-4682, 2020.

[31] F. S. Mustofa and A. Kusumawardhani, "Pengaruh Stock Selection Ability Dan Market Timing Ability Terhadap Kinerja Reksa Dana Syariah Saham Menggunakan Model Conditional Dan Unconditional Pada Periode 2009 - 2015," Diponegoro J. Manag., vol. 5, pp. 1-10, 2016.

[32] R. Pasaribu and D. Kowanda, "Pengaruh suku bunga sbi, tingkat inflasi, ihsg, dan bursa asing terhadap tingkat pengembalian reksa dana saham," J. Akunt. dan Manaj., vol. 25, no. 1, 2014.

[33] L. N. Listiawati and V. S. Paramita, "Pengaruh Tingkat Suku Bunga , Inflasi , Debt To Equity Ratio , Dan Ukuran Perusahaan Terhadap Yield Obligasi Pada," J. Manaj., vol. 15, no. 1, pp. 33-51, 2016.

[34] P. I. "Factors affecting performance of mutual funds in K. . (2015). Amunga, "Factors affecting performance of mutual funds in Kenya," University of Nairobi, 2015. 